\title{
"Those rebellious Hollanders": The Changeling's Double Dutch
}

\author{
Mark Hutchings \\ University of Reading
}

\begin{abstract}
The Changeling (1622) fits neatly into a familiar anti-Spanish narrative, one so well established in criticism as to obscure the wider international picture. Early in the play a reference to England's erstwhile ally against Spain is mentioned in passing, and no more is made of the Dutch naval victory over the Spanish in 1607. But this may have resonated in ways that complicated the play's anti-Spanish sentiment. The enduring resonance of the contemporaneous Amboyna Massacre of 1623 suggests a more complicated reception of The Changeling than critics have allowed for. Even in 1622, when the play was most likely first performed, tensions with the Dutch were on the rise, and the apparent nostalgia for the Protestant alliance which the Treaty of London of 1604 had brought to an end was complicated by the emergence of an empire that would outstrip Spain's and gradually replace it as England's chief rival.
\end{abstract}

KEYWORDS: Anglo-Spanish relations; Anglo-Dutch relations; The Changeling, Amboyna massacre; Thomas Middleton; William Rowley.

Modern editors of The Changeling, ${ }^{1}$ and scholars drawn to a play whose strikingly modern exploration of human psychology guarantees regular revivals, rightly point to the wider context in which the play first operated, towards the end of the reign of the first Stuart monarch. Of the two dramatists behind the play, Thomas

${ }^{1}$ All references to The Changeling are to the earliest quarto, printed for Humphrey Mosley in 1653; italics original, act 1. For a modern reprint, see Bawcutt (1973).

$$
\text { C. ederi 24 (2014: 143-156) }
$$

https://doi.org/10.34136/sederi.2014.7 
Middleton and William Rowley, the former especially has long been regarded as a "political writer," in the sense that a number of his plays are considered to be sympathetic, implicitly or explicitly, to a broadly Protestant fear of and antagonism towards the Church of Rome, and most especially England's main rival, Habsburg Spain (see Heinemann 1980, Limon 1986, and Bromham and Bruzzi 1990). Both playwrights' careers coincided with and in various ways drew directly upon controversies that arose during James I and VI's reign (1603-1625), which began with peace overtures towards Spain, culminating in the Treaty of London signed in 1604, and ended with the two countries on the brink of another war that would come in September 1625 , some six months after James's death. For the entire Jacobean era the quest for a lasting international peace on which James and his queen, Anna of Denmark, had embarked overshadowed politics and social relations in the domestic realm. In this environment dramatists found readymade and indeed incendiary material. Middleton, famously, would satirize Spain's notorious ambassador, Conde de Gondomar, and the plan to match Prince Charles with the Spanish Infanta in A Game at Chess, which ran for nine consecutive days at the Globe in 1624, until Gondomar's successor ambassador's complaint to the Privy Council led to its banning by a furious James (see Howard-Hill 1995:192-213, and Taylor and Lavagnino 2007:865-873). The performance of The Changeling at court, in January 1624, in the wake of the Prince of Wales's return from his abortive mission to Madrid in 1623 to secure the hand of the Infanta, may well have offered both a cautionary tale and reassurance to Charles (in whose honour the play was staged) and to the elite audience that England had, after all, escaped Spain's clutches (Hutchings 2012). Both plays exemplify how Jacobean drama addressed topical issues, each through the veil of rather different kinds of allegory.

Such is the overwhelming narrative of anti-Spanish sentiment both at the time, in terms of the politics of Jacobean England briefly rehearsed here, and in the modern historicizing of the play in recent criticism - that it is all too easy to reduce the play to a cipher of and for Protestant opposition towards Spain and, less stridently for sure, as a covert attack on a monarch popularly believed to be naïve at best in his dealings with Catholic Europe; married as he was to a queen who openly professed her adherence to the "old religion," he continued to reject requests for aid from the exiled Elector Palatine 
and the Queen of Bohemia, his daughter Elizabeth. (That it was Elizabeth's own company of actors who staged The Changeling, not only at the Phoenix but at court too, was a delicious irony not perhaps lost on those present at Whitehall.) Yet as well as calling up a longstanding narrative, The Changeling operated in a "present" of shifting sands - sands which shifted as the "now" of performance changed, in the course of the play's staging and revival during the seventeenth century. As with all plays that lived on beyond their immediate, originating moment, Middleton and Rowley's collaboration was a hostage to historical fortune: the context to which the text first referred was not stable - or rather, that initial contextual frame was subject to the overlay of passing time and changing conditions of reception. One such moment in this play is indicative of how textual and performance transmission carries with it the potential for irony quite irrespective of notional "intentions," either those of the original playwrights or the agents behind later revivals and printings. Indeed, in this case it is an apparently minor detail in the principal source on which Middleton and Rowley relied that may have complicated, however obliquely, the political/ religious binary on which the play relies, first in 1622, and then subsequently.

The Changeling is fairly faithful to its main source, John Reynolds' The Trivmphs of Gods Revenege, Against the crying, and execrable Sinne of Murther (first published in 1621 and popular throughout the century), which does not allude directly to the war that had pitted England against Spain for the last twenty years of Elizabeth's reign. ${ }^{2}$ But a clear reference to England's erstwhile allies in the conflict served to remind playgoers in 1622 not only of the broader political canvas underpinning the tragedy to follow within the walls of Alicante but also the failure of England to continue that fight, especially now with Protestant Europe, as it appeared to many, under siege. Moreover, such a reminder underscored the fact that the 1604-1605 peace, under the terms of which England had left the Dutch to fight on alone, now threatened consequences that would realize many Protestants' worst fears: an Anglo-Spanish marital

\footnotetext{
${ }^{2}$ The Trivmphs of Gods Revenege was reprinted in 1622, 1623, 1624, 1635, 1639, 1640, $1656,1657,1661,1663,1669,1670$, and 1679 . The main difference is the transposition of the roles of the main protagonists: in Reynolds, Alsemero is the villain, not De Flores.
} 
alliance. ${ }^{3}$ As the play's editors have pointed out, the play refers unambiguously to a subsequent truce negotiated between the Dutch and the Spanish that had elapsed just the previous year, 1621: for playgoers this may have suggested that hostilities might - and should, with England returning to the fray - be renewed. However, the politics of this brief sequence in the play are by no means as straightforward as they appear. Relations between England and the Low Countries had changed markedly since the years of the Protestant alliance against Habsburg Spain; indeed, later in the century the play's recollection of that war must have rung rather hollow, in the light of what had followed. In this moment, then, the play's meaning(s) rested on a textual palimpsest, present contextualization overlaying the historical past.

In terms of the text itself, the question of the play's "present" is of interest here, and it depends in fact on the very passage to be discussed. In the allusion to the Treaty of Antwerp of 1609 the posttruce period is evoked, placing the action in the immediate present, as both Alsemero's and Vermandero's use of the past tense when referring to "the late League" and in "I, I, 'twas time to breath" respectively, makes clear. ${ }^{4}$ The play opens with Alsemero musing over his encounter with Beatrice-Joanna, with whom he is smitten; following a lengthy exchange between the two would-be lovers her father enters, and upon his daughter's urging him that Alsemero is "much desirous|To see your castle," a cautious Vermandero wary of "strangers" expresses a wish to "know | Your countrey." It transpires that Alsemero, from neighbouring Valencia, is the son of John de Alsemero, an old friend and comrade-in-arms of Vermandero's, whose death in battle he now recalls:

an unhappy day

Swallowed him at last at Gibralter

\footnotetext{
3 Securing dynastic marriages was part of James and Anna's plan from the very beginning of the peace process in late 1603: marrying the Stuart offspring into both Catholic and Protestant royal houses would, the new monarch believed, help prevent future conflict. The death of Henry, Prince of Wales, in 1612, threatened to derail this plan, but Elizabeth's proposed marriage to the Elector Palatine went ahead in early 1613, though overshadowed by her brother's death. This, in turn, made a Catholic match for the new, unmarried heir, Charles, essential, though as it turned out Charles would marry a French rather than Spanish Catholic.

${ }^{4}$ Modern editors emend the 1653 quarto text to "Aye, aye" and "breathe;" italics added in both quotations.
} 
In fight with those rebellious Hollanders,

Was it not so?

The allusion, as editors recognize, is to Spain's defeat off Gibraltar at the hands of the Dutch on 25 April 1607. Much rests on what is for modern readers the apparently innocuous phrase "those rebellious Hollanders," and the offstage political context it conveys. For an English Protestant audience in 1622 it may well have served to "distance" spectators from the play, alienating them from the tragedy unfolding of Spaniards now established as antagonists of the Dutch (and English) - alienating, that is, in the sense of disrupting a collectively empathetic audience environment for the characters in the tragedy. This past-evoked-in-the-present is underscored in Alsemero's response:

Whose death I had reveng'd,

Or followed him in Fate, had not the late League

Prevented me.

Gibraltar serves as a reminder to playgoers not only that the Dutch had continued the fight alone, but that, as in 1607, in 1622 the Protestant cause was being neglected by James, who had abandoned his own daughter and, moreover, sought to match his heir to the Habsburgs.

And yet this reference to the heroic Dutch might be considered to be rather less securely rooted in an evocative past so convenient for this Protestant narrative. For in drawing attention to one contrasting situation Middleton and Rowley's play cannot avoid calling up another, bringing the past into collision with the present. As much as it apparently suited the dramatists' purposes to remind spectators of a Protestant victory over the Spanish, they did not choose an English triumph - the defeat of the armada in 1588, for example, or the sack of Cadiz in 1596 (the latter, like Gibraltar, only just down the coast from Valencia, after all). Either (or others) might equally well have served the purpose of establishing a form of "alienated" engagement between spectators and play, distancing the audience's sympathy for or interest in the drama conjured in front of them. But instead they followed The Trivmph of Gods Revenege almost to the letter, "Historie IV" setting out the protagonist's history as follows:

In Valentia (an ancient and famous Cittie of Spaine) there dwelt one Don Pedro de Alsemero, a young Cauallier, whose father, Don 
Iuan de Alsemero) [sic] beeing slayne by the Hollanders in the Sea fight at Gibralter, he resolued to addict himselfe to Nauall \& sea actions, thereby to make himselfe capeable to reuenge his fathers death: a braue resolution, worthy the affection of a sonne, and the generosite of a Gentleman! (Reynolds 1621:106) ${ }^{5}$

While Reynolds makes clear that Alsemero plans to travel from Alicante to Malta - the scene of the famous siege of 1565 - The Changeling does not elaborate on the reason for the Malta voyage, thus restricting the play's geopolitical terms of reference to the

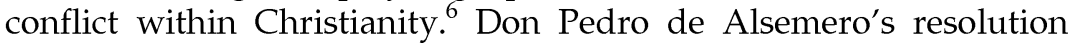
gestures towards the historical Christian struggle against the Ottoman Empire: his desire to "reuenge his fathers death" at the hands of the Dutch is redirected against the Turk. Reynolds' "Hollanders" may have distantly recalled the Protestant struggle against Catholic Spain, but as the century wore on it is likely that this was overridden by readers' knowledge of the growing strength of the Dutch Empire. In The Changeling, similarly, the Dutch presence fleeting though it is - is uncannily suggestive of the shift in power that was well underway when Reynolds's tale of Alsemero pere et fils was given a different form by Middleton and Rowley. It is in the play, however, staged before English Protestant audiences, that the changing international landscape is most marked, particularly if we examine the shifting context in which it operated over the course of the century. Long before the play was written the Dutch were no longer junior partners in an anti-Habsburg coalition but a power in their own right. As the Habsburg Empire was on the wane, so the Dutch was on the rise.

It would be unwise to claim that The Changeling is a barometer of this shift in European power relations, but this exchange between Vermandero and Alsemero is tantalizing when read in terms of the wider cultural and political contexts in which the play operated. Some years before the first publication of the Reynolds compendium and the staging of the play the struggle between Catholic and

\footnotetext{
${ }^{5}$ The long 's' has been silently modernized; Bawcutt provides an abridged version of the Reynolds text, 1958:113-127.

${ }^{6}$ Jasparino's remark, on Beatrice-Joanna's first entrance and Alsemero's greeting in the first act (B2; I.i in modern editions), 'this will be stranger and better news at Valentia, then if he had ransom'd half Greece from the Turk', is perhaps a residual trace of the wider geopolitics implied in Reynolds.
} 
Protestant powers had become complicated locally, as it were, by what A.A. Bromham and Zara Bruzzi call "the aggression of Dutch mercantile expansion," the effects of which were being felt in London, both among merchants and at the highest political levels, and aired in print (1990:41). The East India Company (EIC) had been founded in London in 1602, and the Dutch East India Company (VOC) followed only two years later. The Dutch soon established themselves as the preeminent European power in the Far East, exploiting the lucrative trade in spices, for which there was now a considerable European demand and vast profits to be made. Needless to say, this involved the subjugation and brutalization of native populations that is the familiar hallmark of European imperialism. By securing outposts garrisoned by its soldiers and protected by a flotilla of ships, the Dutch hoped to prevent the EIC from sharing in this trade, and this led to skirmishes between the countries' respective navies. Tensions had become such that, following a series of armed encounters - in December 1618, for example, England lost no fewer than seven ships (Bassett 1960:10) an agreement was signed in 1619 that would allow English merchants limited access to the trade and the ports established under Dutch jurisdiction in return for contributing to the upkeep of the Dutch garrisons (Bassett 1960:4). Under the terms of the treaty the English were prohibited from establishing bases of their own, and in 1621, apparently as a result of the terms being broken, "several English trading stations in the East Indies were seized by the Dutch" (Chancey 1998:587). While the politics of this clash between erstwhile Protestant allies were further complicated by the outbreak of the Thirty Years' war in 1618, which once again pitted Protestants against Catholics and placed James's peacemaking (and his failure to support his daughter and the Elector Palatine, exiled in The Hague) under renewed scrutiny at home, the replaying of Anglo-Dutch tensions through the medium of print kept the crisis on the boil, particularly when, as will be related shortly, a diplomatic incident occurred that would resonate for decades.

The 1621 clash precipitated a pamphlet war. The Hollanders Declaration of the affaires of the East Indies or Trve Relation of That Which Passed in the Ilands of Banda, in the East Indies: In the yeare of our Lord God, 1621. and before. - "Faithfully Translated according to the Dutch copie," proclaims the 1622 title-page - was answered by a series of EIC pamphlets, A Courant of Newes from the East India. A True Relation 
of the Taking of the Ilands of Lantore and Polaroone, A Second Courant of Newes From the East India in Two Letters, and An Answer to the Hollanders Declaration, Concerning the Occurents of the East India all appearing in $1622 . .^{7}$ In this way, as Karen Chancey shows, the EIC sought to publicise its grievances, and as the better-known Thomas Scott pamphlets (on which Middleton drew extensively for A Game at Chess) demonstrate, such attempts to influence foreign policy through an emerging public sphere established a pattern that alarmed James, leading to the issuing of two proclamations in December 1620 and July 1621 "against excesse of Lavish and Licentious Speech of matters of State" (McRae 2004:97). Nevertheless, and for good reason, the EIC's efforts would intensify in that crucial year 1624 .

The Hollanders Declaration of the affaires of the East Indies sets out Dutch claims to hegemony in the Far East, which dates to a treaty negotiated in 1609:

All the Ilands of Banda, from the tenth of August 1609. were by a speciall treaty \& agreement made with the Orang-cayas, or Magistrates of the fore-said Ilands, were put vnder the protection of the high and mighty, the States generall of the vnited Prouinces, on condition to defend them from the [sic] Portugall, and other their Enemies, prouided that they of the said Ilands are bound to deliuer vnto the Fort called Nassau, or vnto the Committees of the said Company, all their fruits or spices at a certain price, and so forth, as by the said treaty of agreement more at large appeareth. (1)

But the key event in 1609, in fact, was a European agreement which made Dutch ambitions possible - the Treaty of Antwerp, or "the late League," as Alsemero puts it, proposed by the Dutch and accepted by the Spanish, under the terms of which Spain allowed the Dutch to practice free trade, where previously the Dutch had been prevented from operating in Habsburg territories. It was this that created favourable conditions for the expansion of the Low Countries' overseas trade, particularly through the VOC in the Far East. While on the surface, then, the reference in the play to the 1609 Treaty of

\footnotetext{
${ }^{7}$ Despite the title-page claim of The Hollanders Declaration of the affaires of the East Indies or Trve Relation of That Which Passed in the Ilands of Banda, in the East Indies: In the yeare of our Lord God, 1621, such subterfuge was not uncommon: far from being printed in Amsterdam, as Early English Books Online indicates this text almost certainly came off the press of Edward Allde.
} 
Antwerp serves as a reminder that England under James had failed and was continuing to fail to support Protestants in their battle with the forces of Rome, Alsemero's remark surely resonated in quite different ways for many in 1622, and subsequently. Ironically - in the form of (meta-)dramatic irony activated by the knowledge playgoers brought to the theatre - the long-term ramifications of the breach between England and the Low Countries in 1604 were that the latter would pose a commercial and ultimately military threat to the former.

Although, inevitably, the record of performances of The Changeling is (as it is for every other play of the period) far from complete, what evidence there is indicates that the play was a popular one during the years up to 1642 , when Parliament closed the playhouses; it was printed (for the first time) in the Interregnum; and it was revived when the theatres reopened in the Restoration, and subsequently reprinted. While the first surviving record of performance is that at court on 4 January 1624, this was almost certainly not the first time it was staged, and there seems no reason to doubt that the Queen of Bohemia's Men presented it sometime after it received its licence from the Master of the Revels on 7 May 1622. N.W. Bawcutt cites a reference in the Middleton/Rowley/ Ford/Dekker collaboration The Spanish Gypsy (1623) to indicate it had been staged by then (Bawcutt 1958:xxvi). How frequently it was on the stage between 1622 and 1624 is unknown, but according to G.E. Bentley it was Christopher Beeston, owner of the Phoenix playhouse, rather than the company itself, who held the rights to the play: while the Queen of Bohemia's Men ceased playing in 1625, the title-page of the earliest quarto (1653) associates it with both the Phoenix and the Salisbury Court playhouse, which dates from 1629, and a contemporary saw the play in 1634/ 5 (Bentley 1942-1968:I.186187, II:654-657, I:254; cited in Bawcutt 1958:xxv); The Changeling was confirmed by the Lord Chamberlain as belonging to Beeston fils in 1639 (Bawcutt 1958:xxvi), which suggests that its value was high, as was recognized later in the century. Bawcutt cites three references recalling the play during the Interregnum, and the first quarto brought out by Humphrey Moseley may have been the basis for a revival at the Phoenix in 1659; a year later Sir William Davenant staged the play at Salisbury Court, which according to one playgoer, Samuel Pepys (perhaps inaccurately), was "the first time it hath been acted these twenty years, and it takes exceedingly" (Bawcut 
1958:xxviii); when The Changeling was reprinted a second time, in 1668, the title-page indicates that it had been revived in 1661 at Davenant's new theatre, in Lincoln's Inn Fields (Bawcutt 1958:xxix).

How this stage/print history and the play's continuance in the cultural memory signified with regard to the moment under discussion is impossible to say. But three related factors point to its possibility. The first is a notorious incident from the early 1620s, the second is the frequency with which this event was recalled and represented in print, and the third is the continued and indeed growing tension between the English and Dutch in the seventeenth century, which saw no fewer than four outbreaks of war, during each of which the 1623 incident was conjured anew as anti-Dutch propaganda.

On 29 May 1624 news of what soon became known as the "Amboyna Massacre" reached England. On 9 March the previous year ten English merchants suspected of plotting against the Dutch garrison in Amboyna had been tortured and executed; as Karen Chancey observes, the episode "played an important role in English politics under the early Stuarts, and influenced English/Dutch relations for a century" (1998:583). The incident provoked outrage and spawned numerous pamphlets and graphic broadsides, such as News out of East India: Of the cruell and bloody vsage of our English Merchants and others at Amboyna, by the Netherlandish Governour and Councell there., which features an illustration of a man about to be beheaded and, in the background, an early form of water torture. The EIC itself was behind A True Relation of the Unjust, Cruel and Barbarous Proceedings Against the English at Amboyna in the East Indies, by the Neatherlandish Governour and Councel There (1624); the print-run itself tells a story: some two thousand appeared, and "circulated in England - with the nobility who resided in and around London receiving free, specially bound copies" (Chancey 1998:588). In a letter to Sir Dudley Carleton of 5 June 1624 John Chamberlain records his reaction to

newes how barbarously the Hollanders have dealt with our men in the East Indies in cutting of ten of our principall factors heads after they had tortured them, upon colour of a plot they had to surprise their fort at Amboyna [...] the rest of the English there have sent a protest, against this manner of proceeding, which doth disharten their friends and those that otherwise wish them 
well, that cannot speake nor heare of this their insolence without much indignation. (McClure 1939:II.562-563)

A month later, to the same correspondent, he writes that

the case is much commiserated by all sorts of people and hath so much alienated our affections that we crie out mainly [i.e. strongly] for revenge of such injustice and indignitie; and the King takes yt so to heart that he speakes somewhat exhuberantly, and I could wish he wold say lesse so he wold do more: for my part I shot my bolt at first, that if they were no wiser then I, we shold stay or arrest the first Indian [i.e. VOC] ship that comes in our way and hang up vpon Dover cliffes as many as we shold find faultie or actors in this busines, and then dispute the matter afterwards. (McClure 1939:II.569-570)

Strongly felt though such sentiment was, as Chancey points out there was no prospect that James would act against the Dutch when, in 1624 with the Spanish Match plans in ruins and relations with Spain deteriorating, a rapprochement with fellow Protestants was of the essence. Indeed, in the same month as Chamberlain was writing to Carleton England signed a treaty according to which English troops would serve under Dutch command in case of any attack from Spain (Limon 1986:143; Chancey 1998:592). For their part the Dutch were unwilling to bring the perpetrators of the Amboyna killings to justice, and in any case maintained that the Englishmen had indeed been plotting to capture the fort at Victoria; the case dragged on for years, and shortly England and Spain were once again at war.

However, if in the short term the Amboyna killings were subsumed by realpolitik, in the longer term the incident served culturally and politically as a rallying call against the Dutch. Amboyna came to stand for Dutch perfidy, being rolled out when tensions led to full-scale war, as they did in the First Anglo-Dutch War (1552-1554), the Second (1665-1667), the Third (1672-1674), and the Fourth (1680-1684). Pamphlets first printed in the 1620s, such as A True Relation of the Unjust, Cruel and Barbarous Proceedings Against the English at Amboyna in the East Indies, by the Neatherlandish Governour and Councel There (1624) were reprinted on the eve of these later conflicts in 1651, 1665, and 1672. Chamberlain refers in a letter to Carleton of 26 February 1625 to "a play or representation of all the busines of Amboyna redy to be acted," only for "the play [to be] forbidden" (McClure 1939:II.602; Limon 1986:4), but in 1672 John 
Dryden did compose a play, Amboyna: A Tragedy. Indeed, the 1623 incident would be invoked by Milton on a number of occasions, including in Paradise Lost (Markley 2006:82-83), it recurs in Defoe's writings, and Swift christened the ship in Book three on which Gulliver returns to England from Japan The Amboyna of Amsterdam (Markley 2006:18; Gardiner 1991:235). The "Amboyna Massacre" thus served as a touchstone for the troubled relations between England and the Low Countries throughout much of the seventeenth century. ${ }^{8}$

How far the cultural and political resonance of Amboyna elicited from playgoers and readers of the play an ironic understanding of the exchange between Vermandero and Alsemero - to what extent, indeed, playgoers were alienated from the Dutch as well as the Spanish in this moment - is of course is impossible to gauge. If the outbreaks of war later in the century made such a response more likely then, it is worth bearing in mind that relations had deteriorated much earlier, and to such an extent as to make an event like Amboyna possible. The 1604 peace with Spain had been unpopular with many Protestants, Dutch and English alike: even before the treaty was signed, the third of the eight pageants designed for James's coronation entry into the capital on 15 March, sponsored by the Dutch community, "implicitly argued against the AngloSpanish peace then being negotiated in nearby Westminster" (Smuts 2007:222). While many Protestants saw their co-religionists as natural allies against the perceived threat from Spain, however, the Dutch had made their own advantageous treaty with the Spanish in 1609. Brief though the reference to the "late league" is, the play offered playgoers a more complex perspective on the international picture than has been appreciated - perhaps as early as its first staging; indeed, the 1607 battle off Gibraltar could be seen (and perhaps was) less as a Protestant victory over Spain than a sign of increasing Dutch power. Outside the playhouse, the Dutch no longer could be considered automatically an ally of England, a state of affairs whose roots might be traced back to 1604 but which probably lie in the larger political and economic forces driving the empire building that would characterize their mutual struggle for the best part of the new century.

\footnotetext{
${ }^{8}$ See especially Gardiner (1991) for an account of this narrative.
} 


\section{References}

Bassett, D.K. 1960. "The 'Amboyna Massacre' of 1623." Journal of South East Asian History 1/2: 1-19.

Bentley, G.E. 1942-1968. The Jacobean and Caroline Stage. 7 vols. Oxford: Clarendon Press.

Bromham, A.A., and Zara Bruzzi 1990. The Changeling and the Years of Crisis, 1619-1624: A Hieroglyph of Britain. London: Pinter Publishers.

Chancey, Karen 1998. "The Amboyna Massacre in English Politics, 16241632." Albion: A Quarterly Journal Concerned with British Studies 30/4: 583598.

Gardiner, Anne Barbeau 1991. "Swift on the Dutch East India Merchants: The Context of 1672-1673 War Literature." Huntington Library Quarterly 54: $235-252$.

Heinemann, Margot 1980. Puritanism and Theatre: Thomas Middleton and Opposition Drama under the Early Stuarts. Cambridge: Cambridge University Press.

Howard-Hill, T.H.1995. Middleton's Vulgar Pasquin: Essays on A Game at Chess. London: Associated University Presses.

Hutchings, Mark 2012. "The Changeling at Court." Cahiers Elisabéthains 81: 1524 .

Limon, Jerzy 1986. Dangerous Matter: English Drama and Politics in 1623/24. Cambridge: Cambridge University Press.

McRae, Andrew 2004. Literature, Satire and the Early Stuart State. Cambridge: Cambridge University Press.

Markley, Robert 2006. The Far East and the English Imagination, 1600-1730. Cambridge: Cambridge University Press.

McClure, N.E. ed. 1939. The Letters of John Chamberlain. 2 vols. Philadelphia: American Philosophical Society.

Middleton, Thomas 1993 (1624). A Game at Chess. Ed. T.H. Howard-Hill. Manchester: Manchester University Press.

and William Rowley 1958 (1622). The Changeling. Ed. N.W. Bawcutt. Manchester: Manchester University Press. and William Rowley 1973 (1622). The Changeling. Ed. N.W. Bawcutt. London: The Scolar Press.

Reynolds, John 1621. The Trivmphs of Gods Revenege. London. 
M. Hutchings

Smuts, R. Malcolm, ed. 2007. "The Whole Royal and Magnificent Entertainment." Thomas Middleton: The Collected Works. Gen. Eds. Gary Taylor and John Lavagnino. Oxford: Oxford University Press. 219-279.

Taylor, Gary 1994. "Forms of Opposition: Middleton and Shakespeare." English Literary Renaissance 24/2: 283-314.

— and John Lavagnino, gen. eds. 2007. Thomas Middleton and Early Modern Textual Culture: A Companion to the Collected Works. Oxford: Oxford University Press.

How to cite this note:

Hutchings, Mark. "'Those rebellious Hollanders': The Changeling's Double Dutch." SEDERI 24 (2014): 143-156.

Author's contact: m.p.v.hutchings@reading.ac.uk

Submission: 04/o9/2013 Acceptance: 24/12/2013 